\title{
NILAI KETAKTERATURAN TOTAL DARI EMPAT COPY GRAF BINTANG
}

\section{Corry Corazon Marzuki ${ }^{*}$, Yusnita Sari ${ }^{2}$, Abdussakir ${ }^{3}$, Fitri Aryani $^{4}$,}

\author{
1,2,4 Jurusan Matematika, Fakultas Sains dan Teknologi, UIN Sultan Syarif Kasim Riau, \\ Jl. HR. Soebrantas No. 155 Simpang Baru, Panam, Pekanbaru, 28293 \\ ${ }^{3}$ Program Magister Pendidikan Matematika, Fakultas Ilmu Tarbiyah dan Keguruan, UIN Maulana Malik \\ Ibrahim Malang, Jl. Gajayana 50, Malang, 65144 \\ Email: corry@uin-suska.ac.id, yusnitasari059@gmail.com, sakir@mat.uin-malang.ac.id, \\ khodijah fitri@uin-suska.ac.id \\ *penulis korespondensi
}

\begin{abstract}
Let $G=(V, E)$ is a graph and $k$ is a positive integers. Total labeling- $k$ on $G$ is a mapping $f: V \cup E \rightarrow\{1,2, \ldots, k\}$. The weight of the vertex $x$ is represented by $w_{f}(x)=$ $f(x)+\sum_{u x \in E} \lambda(u x)$ and the weight of the edge $x y$ is represented by $w_{\lambda}(x y)=\lambda(x)+$ $\lambda(x y)+f(y)$. A total- $k$ labeling of $G$ is called a tottaly irregular total labeling, if the weight of every two distinct vertices are different and the weight of every two distinct edges are different. The minimum $k$ such that a graph $G$ has a totally irregular total $k$-labeling is called the total irregularity strength of $G$, denoted by $t s(G)$. In this paper obtained ts $\left(4 S_{n}\right)=2 n+1$ where $n$ is a positive integer and $n \geq 3$.
\end{abstract}

Keywords: four copies of star, total irregularity strength, totally irregular total labeling.

Abstrak. Misalkan $G=(V, E)$ adalah suatu graf dan $k$ adalah bilangan bulat positif. Pelabelan- $k$ total pada graf $G$ adalah suatu pemetaan $f: V \cup E \rightarrow\{1,2, \ldots, k\}$. Bobot titik $x$ dinyatakan $w_{f}(x)=f(x)+\sum_{u x \in E} f(u x)$ dan bobot sisi $x y$ dinyatakan $w_{f}(x y)=f(x)+$ $f(x y)+f(y)$. Suatu pelabelan- $k$ total dikatakan tak teratur total, jika bobot setiap titik berbeda dan bobot setiap sisi berbeda. Nilai ketakteraturan total (totally irregularity strength) dari graf $G$ dinotasikan dengan $\operatorname{ts}(G)$ adalah nilai $k$ minimum atau label terbesar minimum yang digunakan untuk melabeli graf $G$ dengan pelabelan- $k$ total tak teratur total. Dalam makalah ini diperoleh nilai ketakteraturan total 4 copy graf bintang $S_{n}$ adalah $t s\left(4 S_{n}\right)=2 n+$ 1 dengan $n$ merupakan bilangan bulat positif dan $n \geq 3$.

Kata kunci: empat copy graf bintang, nilai ketakteraturan total, pelabelan total tak teratur total.

\section{PENDAHULUAN}

Teori graf merupakan salah satu cabang ilmu matematika yang menarik untuk dibahas, dengan mengkaji dan menganalisis model atau rumusan. Permasalahan yang dirumuskan dengan teori graf dibuat sederhana, yaitu diambil aspek-aspek yang diperlukan dan dibuang aspek-aspek yang lainnya. [11].

Teori graf muncul pertama kali pada tahun 1736 ketika seorang matematikawan Swiss bernama Leonardo Euler mencoba mencari solusi yang menggambarkan suatu masalah lintasan yang melalui jembatan dan pulau di tengah kota Konigberg. Dari permasalahan itu, 
akhirnya Euler mengembangkan beberapa konsep mengenai teori graf. Masalah tersebut digambarkan melalui titik dan sisi yang menghubungkan antar titik, yang akhirnya berkembang dan dikenal dengan graf [10].

Salah satu topik pada teori graf adalah mengenai pelabelan graf. Pada tahun 2007, Baca dkk. [2] mendefinisikan suatu pelabelan graf yang diberi nama pelabelan tak teratur. Ada dua jenis pelabelan tak teratur yang didefinisikan, yaitu pelabelan total tak teratur sisi dan pelabelan total tak teratur titik. Misalkan $G=(V, E)$ adalah suatu graf. Fungsi $f: V \cup E \rightarrow$ $\{1,2,3, \ldots, k\}$ disebut pelabelan- $k$ total tak teratur titik (vertex irregular total $k$-labeling) pada $G$, jika setiap dua titik yang berbeda di $V$ mempunyai bobot yang berbeda. Bobot titik $x$ di $V$ terhadap fungsi $f$ adalah $w_{f}(x)=f(x)+\sum_{x y \in E} f(x y)$. Bilangan bulat positif terkecil $k$ sedemikian sehingga $G$ mempunyai suatu pelabelan- $k$ total tak teratur titik dinamakan nilai total ketakteraturan titik (total vertex irregularity strength) dari $G$ dan dilambangkan dengan $\operatorname{tvs}(G)$.

Pelabelan $f: V \cup E \rightarrow\{1,2, \ldots, k\}$ pada $G=(V, E)$ disebut pelabelan- $k$ total tak teratur sisi jika untuk setiap dua sisi yang berbeda $e$ dan $g$ pada $G$ memenuhi $w_{f}(e) \neq$ $w_{f}(g)$, dimana $w_{f}(e)$ dan $w_{f}(g)$ berturut-turut adalah bobot dari sisi $e$ dan $g$. Bobot dari suatu sisi $e=u v$ di $G$ didefinisikan sebagai $w_{f}(e)=f(u)+f(u v)+f(v)$. Nilai minimum $k$ sehingga $G$ memiliki pelabelan- $k$ total tak teratur sisi dinamakan nilai total ketakteraturan sisi dari $G$ dan dilambangkan dengan $\operatorname{tes}(G)$.

Pada tahun 2013, Marzuki, dkk. [7] memperkenalkan pelabelan tak teratur lain yaitu pelabelan- $k$ total tak teratur total, yang merupakan hasil dari pengombinasian pelabelan- $k$ total tak teratur titik dan pelabelan- $k$ total tak teratur sisi. Marzuki, dkk [7] mendefinisikan pelabelan- $k$ total $f$ sebagai pelabelan- $k$ total tak teratur total dari graf $G$, jika untuk setiap titik $x$ dan $y$ yang berbeda berlaku $w_{f}(x) \neq w_{f}(y)$, dan untuk setiap sisi $x_{1} x_{2}$ dan $y_{1} y_{2}$ yang berbeda berlaku $w_{f}\left(x_{1} x_{2}\right) \neq w_{f}\left(y_{1} y_{2}\right)$. Nilai $k$ terkecil sehingga suatu graf $G$ dapat dilabeli dengan pelabelan- $k$ total tak teratur total disebut nilai ketakteraturan total dari graf $G$, dinotasikan dengan $t s(G)$.

Pada tahun 2015 Tilukay, dkk. [16] memperoleh nilai ketakteraturan total dari graf kipas, roda, buku segitiga, dan grafik persahabatan, yakni $t s\left(f_{n}\right)=\left\lceil\frac{2 n+1}{3}\right\rceil$ untuk $n \geq 3$, $t s\left(W_{n}\right)=\left\lceil\frac{2 n+2}{3}\right\rceil$ untuk $n \geq 3, t s\left(P_{1} \odot S_{n}\right)=\left\lceil\frac{2 n+3}{3}\right\rceil$ untuk $n \geq 3$, dan $t s\left(F_{n}\right)=n+1$ untuk $n \geq 2$. Selain itu, Ramdani, dkk. [13] juga memperoleh nilai ketakteraturan total dari graf regular, yaitu $t s(m G) \leq m(t s(G))-\left\lfloor\frac{m-1}{2}\right\rfloor$. Masih pada tahun 2015, Rahangmetan [12] memperoleh nilai ketakteraturan total dari gabungan terpisah graf roda dan graf buku segitiga $t s\left(m W_{n}\right)=\frac{2 m n}{3}+1$.

Kemudian pada tahun 2017, Marzuki dkk. [8] memperoleh nilai ketakteraturan total dari graf hasil kali comb $P_{m}$ dan $C_{n}$ yakni $t s\left(P_{m} \triangleright C_{4}\right)=\left\lceil\frac{5 m+1}{3}\right\rceil$. Pada tahun yang sama, Julaeha, dkk. [6] menentukan nilai ketakteraturan total dari graf bunga yaitu $t s\left(B_{n}\right)=\left\lceil\frac{4 n+2}{3}\right\rceil$ untuk $n \geq 3$.

Selain itu, Marzuki, dkk. [15] memperoleh nilai ketakteraturan total dari graf butterfly network level 3 yaitu $\operatorname{ts}(B F(3))=17$. Setelah itu, Marzuki, dkk. [9] juga mendapatkan nilai ketakteraturan $p$-copy graf theta tak seragam yaitu $\operatorname{ts}(p \theta(4,4,(1,0,1,0))=2 p+1$.

Pada tahun 2014, Ramdani, R. [13] memperoleh nilai ketakteraturan total dari dua copy graf bintang yaitu $t s\left(2 S_{n}\right) \geq n+1$. Penelitian ini dilanjutkan oleh Marzuki, dkk. [19] pada 
nilai ketakteraturan total dari tiga copy graf bintang. Pada artikel ini akan ditentukan nilai ketakteraturan total dari empat copy graf bintang.

\section{LANDASAN TEORI}

\subsection{Terminologi Graf}

Berikut akan dijelaskan definisi beberapa istilah pada teori graf, yaitu definisi graf, ketetanggaan, bersisian, dan derajat, serta jenis-jenis graf.

Definisi 1 [3] Suatu graf $G$ adalah suatu himpunan berhingga dan tak kosong Vyang dinamakan titik bersama himpunan $E$ dari subhimpunan 2-elemen dari $V$ yang dinamakan sisi. Untuk menyatakan suatu graf $G$ memiliki himpunan titik $V$ dan himpunan sisi $E$, ditulis $G=(V, E)$.

Definisi di atas menyatakan bahwa $V$ tidak boleh kosong, sedangkan $E$ boleh kosong.

Definisi 2 [3] Ujung dari sebuah sisi dikatakan terkait dengan sisi tersebut. Kedua titik yang terkait dengan satu sisi yang sama dikatakan bertetangga. Sedangkan dua sisi dikatakan bertetangga jika terkait dengan satu titik yang sama.

Definisi 3 [9] Derajat suatu titik pada graf adalah banyak sisi yang terkait dengan titik tersebut. Derajat titik $v$ dinotasikan dengan $d(v)$.

Definisi 4 [8] Suatu graf $G$ disebut graf bipartit jika himpunan titiknya dapat dipartisi menjadi dua subhimpunan $X$ dan $Y$ sedemikian sehingga setiap sisi menghubungkan suatu titik di X kesuatu titik di $Y$.

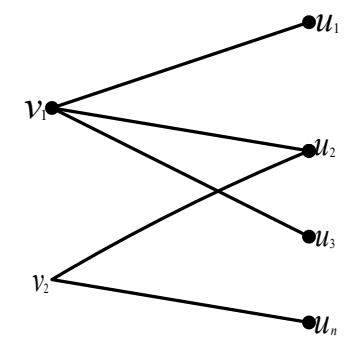

Gambar 1. Graf Bipartit

Definisi 5 [8] Graf bintang dinotasikan dengan $S_{n}$, adalah suatu graf bipat lengkap $K_{1, n}$.

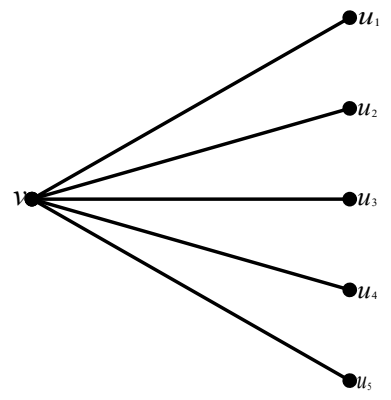

Gambar 2. Graf Bintang $S_{5} \approx K_{1,5}$ 
Definisi 6 [5] Dua graf $G_{1}$ dan $G_{2}$ dikatakan isomorfik $G_{1} \cong G_{2}$ jika terdapat pemetaan satusatu $\varphi: V\left(G_{1}\right) \rightarrow V\left(G_{2}\right)$ sedemikiaan sehingga dua titik $v_{i}$ dan $v_{j}$ bertetangga dalam graf $G_{1}$ jika dan hanya jika titik $\varphi\left(v_{i}\right)$ dan $\varphi\left(v_{j}\right)$ juga bertetangga dalam graf $G_{2}$.

Definisi 7 [4] Gabungan dari dua graf $G_{1}$ dan $G_{2}$ yang dinotasikan dengan $G_{1} \cup G_{2}$ adalah grafyang mempunyai $V\left(G_{1} \cup G_{2}\right)=V\left(G_{1}\right) \cup V\left(G_{2}\right)$ dan $E\left(G_{1} \cup G_{2}\right)=E\left(G_{1}\right) \cup E\left(G_{2}\right)$. Jika $G_{1} \cong G_{2} \cong G$ maka dinotasikan dengan $2 G$ untuk $G_{1} \cup G_{2}$. Pada umumnya, jika $G_{1}, G_{2}, \ldots, G_{n}$ adalah $n$ graf yang isomorfik dengan $G$, maka $G_{1} \cup G_{2} \cup \ldots \cup G_{n}$ dinotasikan dengan $n G$ yang dinamakan n-copy graf $G$.

\subsection{Pelabelan Graf}

Pelabelan graf pertama kali diperkenalkan oleh matematikawan Sedlacek pada Tahun 1963. Pelabelan pada suatu graf adalah pemetaan yang memasangkan unsur-unsur graf (titik/sisi) dengan bilangan bulat positif. Jika domain pemetaan adalah titik, maka disebut pelabelan titik. Jika domain pemetaan adalah sisi, maka disebut pelabelan sisi. Jika domain dari pemetaan adalah titik dan sisi, maka disebut pelabelan total [18].

Bobot (weight) dari suatu elemen graf adalah jumlah dari semua label yang berhubungan dengan elemen graf tersebut [18]. Bobot dari titik $v$ dengan pelabelan $f$ adalah $w_{f}(v)=f(v)+\sum_{u v \in E} f(u v)$. Sedangkan bobot dari sisi $u v$ adalah $w_{f}(u v)=f(u)+$ $f(u v)+f(v)$. Sampai saat ini terdapat beberapa jenis pelabelan graf yang telah dikaji, salah satunya adalah pelabelan total tak teratur. Pelabelan total tak teratur terdiri dari: pelabelan total tak teratur titik, pelabelan total tak teratur sisi dan pelabelan total tak teratur total. Berikut akan dijelaskan mengenai pelabelan total tak teratur total.

\section{a. Pelabelan Total Tak Teratur Titik}

Pelabelan total tak teratur titik merupakan salah satu jenis pelabelan total tak teratur yang diperkenalkan oleh Bača, dkk. Definisi pelabelan total tak teratur titik sebagai berikut.

Definisi 8 [2] Pelabelan- $k$ total dikatakan pelabelan- $k$ total tak teratur titik dari graf $G$, jika untuk setiap titik $u$ dan $v$ yang berbeda maka $w_{f}(x) \neq w_{f}(y)$, dimana $w_{f}(x)=f(x)+$ $\sum_{u v \in E} f(u x)$. Nilai total ketakteraturan titik (total vertex irregularity strength) dari graf $G$, yang dinotasikan dengan tvs $(G)$ adalah label terbesar minimum yang digunakan untuk melabeli graf $G$ dengan pelabelan total tak teratur titik.

Penelitian mengenai nilai tvs $(G)$ dilakukan oleh Bača, dkk., dengan diberikan batas atas dan batas bawah seperti dituliskan pada teorema berikut ini.

Teorema 1 [2] Misalkan $G$ adalah graf $(p, q)$, dengan $p$ adalah banyaknya titik dan $q$ adalah banyaknya sisi. Jika derajat minimum $\delta$ dan derajat maksimum $\Delta$, maka

$$
\left\lceil\frac{p+\delta}{\Delta+1}\right\rceil \leq t v s(G) \leq p+\Delta-2 \delta+1
$$




\section{b. Pelabelan Total Tak Teratur Sisi}

Pelabelan total tak teratur sisi juga diperkenalkan oleh Bača, dkk yang didefinisikan sebagai berikut.

Definisi 9 [2] Pelabelan- $k$ total dikatakan pelabelan-k total tak teratur sisi dari graf $G$, jika untuk sebarang dua sisi $e=u_{1} v_{1}$ dan $w=u_{2} v_{2}$ yang berada di graf $G$ berlaku $w_{f}(e) \neq$ $w_{f}(w)$, dengan $w_{f}(e)=f\left(u_{1}\right)+f(e)+f\left(v_{1}\right)$ dan $w_{f}(w)=f\left(u_{2}\right)+f(w)+f\left(v_{2}\right)$. Nilai total ketakteraturan sisi (total edge irregularity strength) dari graf $G$, yang dinotasikan dengan tes $(G)$ adalah label terbesar minimum yang digunakan untuk melabeli graf $G$ dengan pelabelan total tak teratur sisi.

Penelitian mengenai nilai tes $(G)$ dilakukan oleh Bača, dkk., dengan diberikan batas atas dan batas bawah seperti dituliskan pada teorema berikut ini:

Teorema 2 [2] Misalkan $G=(V, E)$ adalah suatu graf dengan himpunan titik $V$ dan himpunan sisi tak kosong $E$, maka:

$$
\left\lceil\frac{|E|+2}{3}\right\rceil \leq \operatorname{tes}(G) \leq|E|
$$

\section{c. Pelabelan Total Tak Teratur}

Pelabelan total tak teratur total merupakan kombinasi pelabelan total tak teratur titik dan pelabelan total tak teratur sisi. Berikut ini definisi pelabelan total tak teratur total:

Definisi 10 [7] Pelabelan- $k$ total $f$ dikatakan pelabelan- $k$ total tak teratur total dari graf $G$, jika untuk setiap titik $x$ dan y yang berbeda maka $w_{f}(x) \neq w_{f}(y)$, dan untuk setiap sisi $x_{1} x_{2}$ dan $y_{1} y_{2}$ yang berbeda maka $w_{f}\left(x_{1} x_{2}\right) \neq w_{f}\left(y_{1} y_{2}\right)$. Nilai keteraturan total (totally irregularity strength) dari graf $G$, yang dinotasikan $t s(G)$ adalah label terbesar minimum yang digunakan untuk melabeli graf $G$ dengan pelabelan total tak teratur total.

Penelitian mengenai nilai ts $(G)$ dilakukakan oleh C.C. Marzuki, dkk., dengan diberikan batas bawah seperti dituliskan pada teorema berikut ini.

Teorema 3 [7] Untuk setiap graf $G$, maka $t s(G) \geq \max \{\operatorname{tes}(G), \operatorname{tvs}(G)\}$.

Hasil penelitian tentang nilai ketakteraturan total diberikan pada teorema-teorema berikut, di antaranya Ramdani [11] yang mendapatkan nilai ketakteraturan total untuk dua copy graf bintang.

Teorema 4 [13] Misalkan $n \geq 2$, maka ts $\left(2 S_{n}\right)=n+1$.

\section{HASIL DAN PEMBAHASAN}

Hal yang akan dijelaskan dalam hasil dan pembahasan ini yaitu tentang langkahlangkah dalam menentukan nilai ketakteraturan total dari empat copy graf bintang $\left(4 S_{n}\right)$. Beberapa langkah yang dilakukan untuk memperoleh rumus nilai ketakteraturan total dari graf $4 S_{n}$, yaitu: pemberian nama masing-masing titik dan sisi, menentukan batas bawah nilai 
ketakteraturan total pada graf $4 S_{n}$, untuk $n \geq 3$, melakukan pelabelan total tak teratur total pada graf $4 S_{n}$ untuk $n=3,4,5, \ldots, 10$, menentukan rumus pelabelan titik dan pelabelan sisi, menentukan rumus bobot titik dan bobot sisi yang berguna untuk membuktikan bahwa setiap bobot titik dan bobot sisi tidak ada yang sama. Setelah itu, jika terbukti bahwa setiap bobot titik dan bobot sisi tidak ada yang sama maka, terbukti bahwa pelabelan tersebut merupakan pelabelan total tak teratur total.

Graf $4 S_{n}$ merupakan graf yang terdiri dari $4 n$ titik berderajat 1 dan 4 titik berderajat $n$. Definisikan himpunan titik dari graf $4 S_{\mathrm{n}}$ adalah $V\left(4 S_{n}\right)=\left\{u_{i} \mid i=1,2,3,4\right\} \cup$ $\left\{t_{j} \mid j=1,2,3, \ldots, 4 n\right\}$, sedangkan himpunan sisi dari graf $4 S_{n} E\left(4 S_{n}\right)=\left\{u_{i} t_{j}\right\}$, dengan $i=$ 1 dan $j \equiv 1(\bmod 4) ; i=2$ dan $j \equiv 2(\bmod 4) ; i=3$ dan $j \equiv 3(\bmod 4) ; i=4 \operatorname{dan} j \equiv$ $0(\bmod 4)$.

Ilustrasi dari empat copy graf bintang, yang dinotasikan dengan $4 S_{n}$ diberikan pada Gambar 3 berikut.
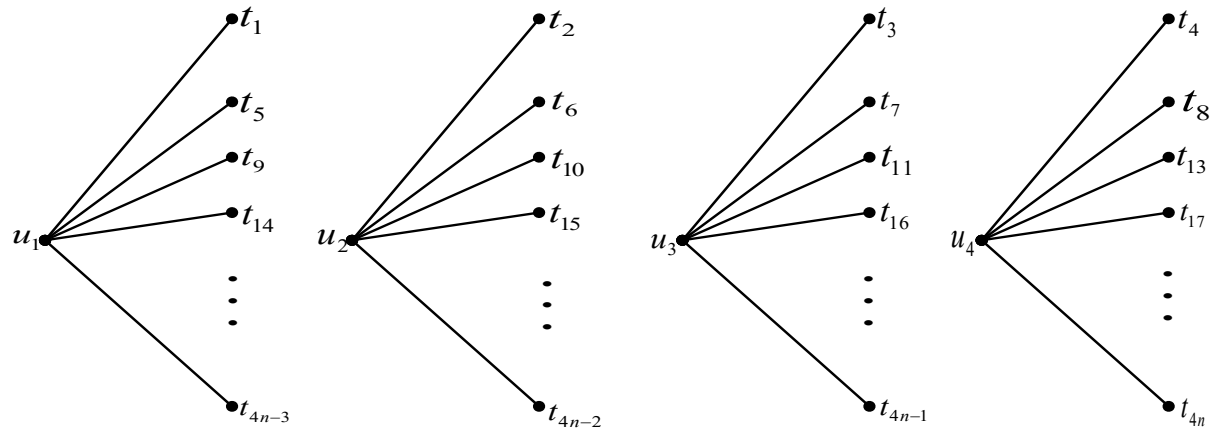

Gambar 3. Ilustrasi empat copy graf bintang $\left(4 S_{n}\right)$

Dari langkah-langkah yang dijelaskan di atas, diperoleh suatu teorema tentang rumus umum nilai ketakteraturan total dari graf $4 S_{n}$ untuk $n \geq 3$ diberikan dalam Teorema 5 berikut:

Teorema 5. Misalkan $4 S_{n}$ adalah empat copy graf bintang dengan $n$ bilangan bulat positif dan untuk $n \geq 3$. Maka

$$
\operatorname{ts}\left(4 S_{n}\right)=2 n+1
$$

\section{Bukti:}

Graf $4 S_{n}$ memiliki $4 n$ titik berderajat 1 dan 4 titik berderajat $n$, maka bobot titik terkecil dari $4 S_{n}$ sedikitnya 2 dan bobot terbesar dari suatu titik berderajat 1 sedikitnya $4 n+1$, sehingga label terbesar dari suatu titik berderajat 1 adalah sedikitnya $\left\lceil\frac{4 n+1}{2}\right\rceil=2 n+1$. Bobot terkecil dari suatu titik berderajat $n$ sedikitnya $4 n+2$ dan bobot terbesar dari suatu titik berderajat $n$ adalah $4 n+5$. Sehingga label terbesar dari suatu titik berderajat $n$ sedikitnya $\left\lceil\frac{4 n+5}{n+1}\right\rceil$. Dengan demikian, diperoleh

$$
\operatorname{tvs}\left(4 S_{n}\right) \geq \max \left\{2 n+1,\left\lceil\frac{4 n+5}{n+1}\right\rceil\right\}=2 n+1
$$


Selain itu, banyaknya sisi dari $4 S_{n}$ adalah $4 n$, sehingga berdasarkan Teorema 2 , diperoleh

$$
\operatorname{tes}\left(4 S_{n}\right) \geq\left\lceil\frac{4 n+2}{3}\right\rceil
$$

Dengan demikian, berdasarkan Teorema 3, diperoleh

$$
t s\left(4 S_{n}\right)=\max \left\{2 n+1,\left\lceil\frac{4 n+2}{3}\right\rceil\right\}=2 n+1
$$

Selanjutnya akan dibuktikan $t s\left(4 S_{n}\right) \leq 2 n+1$. Hal ini akan dibuktikan dengan cara menunjukkan adanya pelabelan- $2 n+1$ total tak teratur total pada graf $4 S_{n}$, untuk $n$ bilangan positif dengan $n \geq 3$.

Definisikan $f:\left(V\left(4 S_{n}\right) \cup E\left(4 S_{n}\right)\right) \rightarrow\{1,2,3, \ldots 2 n+1\}$ yang merupakan pelabelan total pada graf $4 S_{n}$ sebagai berikut:

a) Untuk $n=3,4$.

$$
\begin{aligned}
& f\left(t_{j}\right)=\left[\frac{j}{2}\right\rceil \text { untuk } j=1,2,3,4 n \\
& f\left(u_{i}\right)=\left\{\begin{array}{l}
5 \text { untuk } i=1 \text { dan } n=3 \\
3 \text { untuk } i=2 \operatorname{dan} n=3 \\
4 \text { untuk } i=3,4 \operatorname{dan} n=3 \\
2 \text { untuk } i=1,2 \operatorname{dan} n=4 \\
3 \text { untuk } i=3 \operatorname{dan} n=4 \\
1 \text { untuk } i=4 \operatorname{dan} n=4
\end{array}\right. \\
& f\left(u_{i} t_{j}\right)=\left\lfloor\frac{j}{2}\right\rfloor+1 \text { untuk } i=1 \text { dan } j \equiv 1(\bmod 4) \text { atau } i=2 \text { dan } j \equiv \\
& 2(\bmod 4) \text { atau } i=3 \text { dan } j \equiv 3(\bmod 4) \text { atau } i=4 \text { dan } j \equiv 0(\bmod 4) .
\end{aligned}
$$

b) Untuk $n \geq 5$

$$
\begin{aligned}
& f\left(t_{j}\right)=\left[\frac{j}{2}\right\rceil \text { untuk } j=1,2,3,4 n ; \\
& f\left(u_{i}\right)=\left\{\begin{array}{c}
1 \text { untuk } i=1,2 \\
2 \text { untuk } i=3 \\
4 \text { untuk } i=4
\end{array}\right. \\
& f\left(u_{i} t_{j}\right)=\left\lfloor\frac{j}{2}\right\rfloor+1 \text { untuk } i=1 \text { dan } j \equiv 1(\bmod 4) \text { atau } i=2 \operatorname{dan} j \equiv \\
& 2(\bmod 4) \text { atau } i=3 \text { dan } j \equiv 3(\bmod 4) \text { atau } i=4 \operatorname{dan} j \equiv 0(\bmod 4) .
\end{aligned}
$$

Berdasarkan rumus pelabelan titik dan sisi di atas, maka dapat dirumuskan bobot titik dan bobot sisi dari graf $4 S_{n}$ sebagai berikut.

1) Untuk $n=3$, bobot titik $u_{i}$ dengan $i=1,2,3,4$ adalah $14,15,16,19$ sedangkan bobot titik $t_{j}$ dengan $j=1,2,3,4 n$ adalah bilangan bulat positif berurutan mulai dari 2 sampai 13. Jadi tidak ada bobot titik yang sama. Untuk bobot sisi $u_{i} t_{j}$ dengan $i=$ $1,2,3,4 \operatorname{dan} j \equiv 1(\bmod 4), j \equiv 2(\bmod 4), j \equiv 3(\bmod 4)$ atau $j \equiv 0(\bmod 4) \operatorname{dan} j=$ $1,2,3,4 n$ adalah bilangan positif berurut mulai dari 6 sampai 17. Jadi tidak ada bobot sisi yang sama. 
2) Untuk $n=4$, bobot titik $u_{i}$ dengan $i=1,2,3,4$ adalah 18,22, 23, 25 sedangkan bobot titik $t_{j}$ dengan $j=1,2,3,4 n$ adalah bilangan bulat positif berurutan mulai dari 2 sampai 17. Jadi tidak ada bobot titik yang sama. Untuk bobot sisi $u_{i} t_{j}$ dengan $i=$ $1,2,3,4 \operatorname{dan} j \equiv 1(\bmod 4), j \equiv 2(\bmod 4), j \equiv 3(\bmod 4)$ atau $j \equiv 0(\bmod 4) \operatorname{dan} j=$ $1,2,3,4 n$ adalah bilangan positif berurut mulai dari 4 sampai 19. Jadi tidak ada bobot sisi yang sama.

3) Untuk $n \geq 5$, bobot titik pada graf $4 S_{n}$ adalah sebagai berikut.

a) Untuk $i=1$ dan $j$ genap

$W_{f}\left(t_{j}\right)=f\left(t_{j}\right)+f\left(u_{i} t_{j}\right)=j+1$

Untuk $i=1$ dan $j$ ganjil

$W_{f}\left(t_{j}\right)=f\left(t_{j}\right)+f\left(u_{i} t_{j}\right)=j+1$

b) Untuk $i=2$ dan $j$ genap

$W_{f}\left(t_{j}\right)=f\left(t_{j}\right)+f\left(u_{i} t_{j}\right)=j+1$

Untuk $i=2$ dan $j$ ganjil

$W_{f}\left(t_{j}\right)=f\left(t_{j}\right)+f\left(u_{i} t_{j}\right)=j+1$

c) Untuk $i=3$ dan $j$ genap

$W_{f}\left(t_{j}\right)=f\left(t_{j}\right)+f\left(u_{i} t_{j}\right)=j+1$

Untuk $i=3$ dan $j$ ganjil

$W_{f}\left(t_{j}\right)=f\left(t_{j}\right)+f\left(u_{i} t_{j}\right)=j+1$

d) Untuk $i=4$ dan $j$ genap

$W_{f}\left(t_{j}\right)=f\left(t_{j}\right)+f\left(u_{i} t_{j}\right)=j+1$

Untuk $i=4$ dan $j$ ganjil

$W_{f}\left(t_{j}\right)=f\left(t_{j}\right)+f\left(u_{i} t_{j}\right)=j+1$

e) $W_{f}\left(u_{1}\right)=f\left(u_{1}\right)+f\left(u_{1} t_{1}\right)+f\left(u_{1} t_{5}\right)+f\left(u_{1} t_{9}\right)+f\left(u_{1} t_{13}\right)+\ldots+f\left(u_{1} t_{4 n-7}\right)+f\left(u_{1} t_{4 n-3}\right)$

$$
=n^{2}+1
$$

f) $\quad W_{f}\left(u_{2}\right)=f\left(u_{2}\right)+f\left(u_{2} t_{2}\right)+f\left(u_{2} t_{6}\right)+f\left(u_{2} t_{10}\right)+f\left(u_{2} t_{14}\right)+\ldots+f\left(u_{2} t_{4 n-6}\right)+f\left(u_{2} t_{4 n-2}\right)$

$$
=n^{2}+n+1
$$

g) $\quad W_{f}\left(u_{3}\right)=f\left(u_{3}\right)+f\left(u_{3} t_{3}\right)+f\left(u_{3} t_{7}\right)+f\left(u_{3} t_{11}\right)+f\left(u_{3} t_{15}\right)+\ldots+f\left(u_{3} t_{4 n-5}\right)+f\left(u_{3} t_{4 n-1}\right)$

$$
=n^{2}+n+2
$$

h) $W_{f}\left(u_{4}\right)=f\left(u_{4}\right)+f\left(u_{4} t_{4}\right)+f\left(u_{4} t_{8}\right)+f\left(u_{4} t_{12}\right)+f\left(u_{4} t_{16}\right)+\ldots+f\left(u_{4} t_{4 n-4}\right)+f\left(u_{4} t_{4 n}\right)$

$$
=n^{2}+2 n+4
$$

Sedangkan bobot sisi pada graf $4 S_{n}$ untuk $n \geq 5$ adalah sebagai berikut.

a) Untuk $i=1$ dan $j$ genap

$W_{f}\left(u_{i} t_{j}\right)=f\left(u_{1}\right)+f\left(u_{1} t_{j}\right)+f\left(t_{j}\right)=j+2$

Untuk $i=1$ dan $j$ ganjil

$W_{f}\left(u_{i} t_{j}\right)=f\left(u_{1}\right)+f\left(u_{1} t_{j}\right)+f\left(t_{j}\right)=j+2$

b) Untuk $i=2$ dan $j$ genap

$W_{f}\left(u_{i} t_{j}\right)=f\left(u_{2}\right)+f\left(u_{2} t_{j}\right)+f\left(t_{j}\right)=j+2$ 


$$
\begin{aligned}
& \text { Untuk } i=2 \text { dan } j \text { ganjil } \\
& W_{f}\left(u_{i} t_{j}\right)=f\left(u_{2}\right)+f\left(u_{2} t_{j}\right)+f\left(t_{j}\right)=j+2
\end{aligned}
$$

c) Untuk $i=3$ dan $j$ genap

$$
W_{f}\left(u_{i} t_{j}\right)=f\left(u_{3}\right)+f\left(u_{3} t_{j}\right)+f\left(t_{j}\right)=j+3
$$

Untuk $i=3$ dan $j$ ganjil

$$
W_{f}\left(u_{i} t_{j}\right)=f\left(u_{3}\right)+f\left(u_{3} t_{j}\right)+f\left(t_{j}\right)=j+3
$$

d) Untuk $i=4$ dan $j$ genap

$$
W_{f}\left(u_{i} t_{j}\right)=f\left(u_{4}\right)+f\left(u_{4} t_{j}\right)+f\left(t_{j}\right)=j+5
$$

Untuk $i=4$ dan $j$ ganjil

$$
W_{f}\left(u_{i} t_{j}\right)=f\left(u_{4}\right)+f\left(u_{4} t_{j}\right)+f\left(t_{j}\right)=j+5
$$

Jadi, untuk $n \geq 5$, bobot titik $t_{j}$ yang dinotasikan dengan $w_{f}\left(t_{j}\right)$ dengan $j=1,2,3, \ldots, 4 n$ adalah bilangan bulat postif berurutan mulai dari $2,3, \ldots, 4 n+1$. Sedangkan bobot titik $u_{i}$ dengan $i=1,2,3,4$ yang dinotasikan dengan $w_{f}\left(u_{1}\right)$ adalah $n^{2}+1, w_{f}\left(u_{2}\right)$ adalah $n^{2}+n+1, w_{f}\left(u_{3}\right)$ adalah $n^{2}+n+2, w_{f}\left(u_{4}\right)$ adalah $n^{2}+2 n+4$, sedangkan bobot sisi $u_{i} t_{j}$ yang dinotasikan $w_{f}\left(u_{i} t_{j}\right)$, dengan $i=1$ dan $j \equiv 1(\bmod 4), i=2$ dan $j \equiv$ $2(\bmod 4)$ adalah $j+2$, untuk $i=3$ dan $j \equiv 3(\bmod 4)$ adalah $j+3$, sedangkan untuk $i=4$ dan $j \equiv 0(\bmod 4)$ adalah $j+5$.

Berikut ini akan ditunjukkan bahwa setiap bobot titik pada graf $4 S_{n}$ tidak ada yang sama. Akan ditunjukkan bahwa $w_{f}\left(4 S_{n}\right)<w_{f}\left(u_{1}\right)<w_{f}\left(u_{2}\right)<w_{f}\left(u_{3}\right)<w_{f}\left(u_{4}\right)$. Hal ini akan dibuktikan dengan induksi matematika.

1. Akan ditunjukkan $2 n+1<n^{2}+1$ untuk setiap $n \geq 5$, menggunakan induksi matematika sebagai berikut :

a. Basis Induksi

Akan ditunjukkan untuk $n=5$, berlaku

$2 n+1<n^{2}+1$

Perhatikan bahwa

$2 n+1=2(5)+1=11<26=(5)^{2}+1=n^{2}+1$

b. Langkah Induksi

Asumsikan benar untuk $n=k$, yaitu

$2 k+1<k^{2}+1$

Akan dibuktikan benar untuk $n=k+1$, yaitu

$2(k+1)+1<(k+1)^{2}+1$

$\Leftrightarrow 2 k+3<k^{2}+k+2$

Perhatikan bahwa $2 k+1<k^{2}+1$

(kedua ruas ditambah 2)

$\Leftrightarrow 2 k+1+2<k^{2}+1+2$

$\Leftrightarrow 2 k+3<k^{2}+3$

$\Leftrightarrow 2 k+3<k^{2}+3<k^{2}+3+k-1$

$\Leftrightarrow 2 k+3<k^{2}+3<k^{2}+k+2$

2. Akan ditunjukkan $2 n+1<n^{2}+n+1$

Perhatikan bahwa, untuk $n \geq 5$ 


$$
\begin{array}{ll}
n+n<n^{2}+n & \\
2 n<n^{2}+n & \quad \text { (kedua ruas ditambah }+1) \\
\Leftrightarrow 2 n+1<n^{2}+n+1 &
\end{array}
$$

3. Akan ditunjukkan $n^{2}+n+1<n^{2}+n+2$

Perhatikan bahwa, untuk $n \geq 5$

$n+1<n+2$

$\Leftrightarrow n^{2}+n+1<n^{2}+n+2$

(kedua ruas ditambah $n^{2}$ )

4. Akan ditunjukkan $n^{2}+n+2<n^{2}+2 n+4$

Perhatikan bahwa, untuk $n \geq 5$

$n+2<n+n+4$

$n+2<2 n+4 \quad$ (kedua ruas ditambah $n^{2}$ )

$\Leftrightarrow n^{2}+n+2<n^{2}+2 n+4$

Perhatikan bahwa fungsi $f$ adalah suatu pemetaan dari $V\left(4 S_{n}\right) \cup E\left(4 S_{n}\right)$ ke $\{1,2, \ldots, 2 n+1\}$ dengan setiap titik memiliki bobot yang berbeda dan setiap sisi memiliki bobot yang berbeda. Jadi, $f$ adalah pelabelan total tak teratur total pada graf $4 S_{n}$. Sehingga dapat disimpulkan bahwa $t s\left(4 S_{n}\right) \leq 2 n+1$. Dengan terbuktinya $t s\left(4 S_{n}\right) \geq 2 n+1$ dan $t s\left(4 S_{n}\right) \leq 2 n+1$ maka diperoleh $t s\left(4 S_{n}\right)=2 n+1$.

Berikut ini akan disajikan contoh aplikasi Teorema 9 pada graf $4 S_{n}$ dimana $n=14$. Adapun langkah-langkah dalam menyelesaikan contoh nilai ketakteraturan total dari $4 S_{14}$ adalah sebagai berikut :

1. Menentukan label setiap sisi dan setiap titik dari graf $4 S_{14}$ dengan menggunakan rumus pelabelan titik dan pelabelan sisi.

2. Menentukan bobot setiap sisi dan bobot setiap titik dari graf $4 S_{14}$.

3. Menunjukkan bahwa bobot setiap sisi berbeda dan bobot setiap titik juga berbeda. 

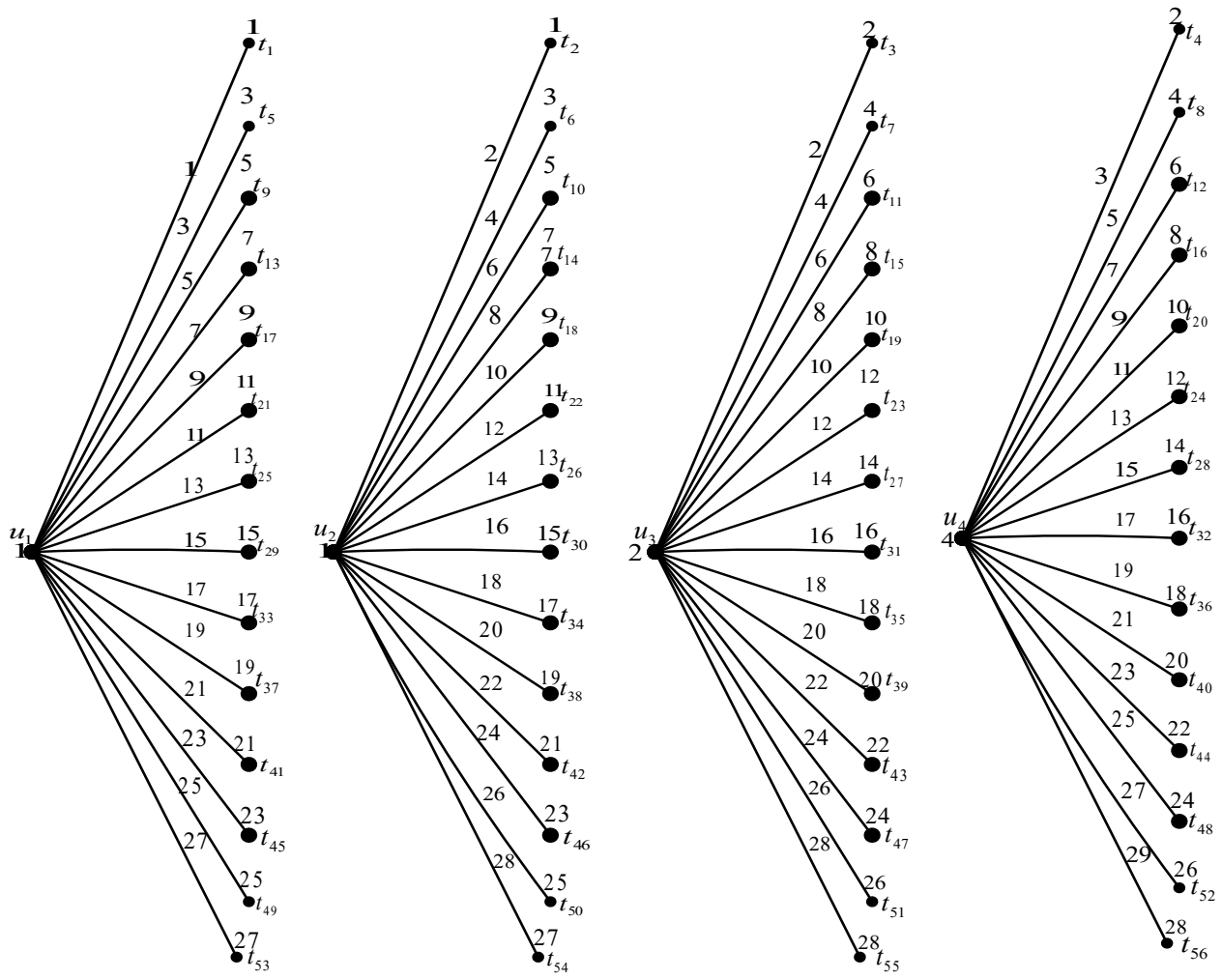

Gambar 4. Pelabelan Total Tak Teratur Total pada $4 S_{14}$

Perhatikan bahwa label maksimum yang digunakan pada Gambar 4 adalah 29. Dengan label maksimum tersebut dapat diperiksa bahwa bobot setiap titiknya berbeda dan bobot setiap sisinya berbeda. Oleh karena itu, pelabelan tersebut merupakan pelabelan-29 total tak teratur total pada graf $4 S_{14}$.

\section{KESIMPULAN}

Berdasarkan uraian di atas tentang nilai ketakteraturan total dari empat copy graf bintang $\left(4 S_{n}\right)$ dapat disimpulkan bahwa $t s\left(4 S_{n}\right)=2 n+1$ untuk $n \geq 3$. Hal ini sudah dibuktikan pada Teorema 9 dengan cara membuktikan bahwa $2 n+1$ merupakan batas bawah dan juga batas atas dari nilai ketakteraturan total pada graf $4 S_{n}$.

\section{REFERENSI}

[1] Amir, Zubaidah. "Matematika Diskrit". Halaman 1-4. Zanafa Publishing, Pekanbaru. 2010.

[2] Bača, M., Jendrol J., Miller, M., dan Ryan, J. "On Irregular Total Labellings" Discrete Math. Vol. 307.Halaman 1378-1388. 2007.

[3] Chartrand, G., Lesniak L., Zhang P., Graphs and Digraphs $5^{\text {th }}$ edition, CRC Press. New York. 2011.

[4] Chartrand, Gary and O. R. Oellermann. (1993). Applied and Algorithmic graph Theory. McGraw-Hill Inc, New York.

[5] Chartrand, Gary. (1986). Introductory Graph Theory. Dover Publications Inc, New York.

[6] Julaeha, S., Luspitasari, I., \& Sukaesih, E. "Pelabelan Total Tak Teratur Total Pada Graf Bunga $\left(F_{n}\right)$ ". J. Istek. Vol. X, No. 1, halaman 6, 2017. 
[7] Marzuki, C.C, Salman, A.N.M. \& Miller, M., "On The Total Irregularity Strength of Cycles and Paths," FJMS. Vol. 82, halaman 1-21, 2013.

[8] Marzuki, C.C., Febrinanda,Y. "Nilai Ketakteraturan Total dari Graf Hasil Kali Comb $P_{m}$ dan $C_{n}$, ,Jurnal Sains Matematika dan Statistika". Vol. 3, halaman 8-15. 2017.

[9] Marzuki, C. C., Handayani, S., Aryani, F. "Nilai Ketakteraturan Total dari p-copy Graf Theta Tak Seragam" . Jurnal Seminar Nasional Teknologi Informasi, halaman 737-740, 2018.

[10] Munir, R. "Matematika Diskrit”. Revisi Kelima. Bandung: Informatika. 2005.

[11] Purwanto. "Teori Graf”. Malang : IKIP MALANG. 1998.

[12] Rahangmetan, R. D. S, Tilukay, M., Rumlawang, F.Y., \& Talakua, M.W. "Nilai Total Tak Teratur Total Dari Gabungan Terpisah Graf Roda Dan Graf Buku Segitiga": Jurnal Ilmu Matematika, Vol. 9, No. 2, halaman 97-102, 2015.

[13] Ramdani, R., "Nilai Total Ketakteraturan Total dari Dua Copy Graf Bintang," J.Math. Fund. Sci. Vol. 8, halaman 4, 2014.

[14] Ramdani, R., Salman, A. N. M., dan Assiyatun, H. "On The Total Irregularity Strength of Regular Graph," Journal of Mathematical and Fundamental Sciences. Vol. 47, halaman 281-295. 2015.

[15] Marzuki, C.C., Sari, M., Aryani, F., Nilai Ketakteraturan Total dari Graf Butterfly Network Level 3, Seminar Nasional Teknologi Informasi, Komunikasi dan Industri (SNTIKI) 11, 2019..

[16] Meilin T.I., Salman, A.M.N., \& Persulessy, E.R., "One the Total Irregularity Strength of Fan, Wheel, Tringular Book, and Friendship Graph" Procedia Computer Science 74 124-131. 2015.

[17] Vasudev, C. “Graph Theory with Application”. Halaman 1,3. New Age international Publisher, New Delhi. 2006.

[18] Wallis W D. "Magic Graphs". Halaman 11. Birkhauser Boston, New York. 2001.

[19] Marzuki, C.C., Yuliana, Muda, Y., Elviyenti, M., Nilai Ketakteraturan Total dari Tiga Copy Graf Bintang, Jurnal Sains, Teknologi dan Industri, Vol. 18, No. 1, Desember 2020, pp.126 - 133. 